\title{
Performance and physiological response of heat stressed growing pullets fed diets
} supplemented with ascorbic acid

Adedeji, B. S. and Ogunwole, O. A.

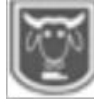
Agricultural Biochemistry and Nutrition Unit, Department of Animal Science, University of Ibadan, Nigeria

Abstract Corresponding address: bs.adedeji@gmail.com; +2347037686167

Effects of dietary supplementation of Ascorbic Acid (AA) on performance and physiological response of growing pullets were investigated in a 7-week trial. In a completely randomized design, Bovan Brown pullets $(n=96)$ aged 12 weeks weighing $0.81 \pm 0.04 \mathrm{~kg}$ were randomly allotted to three treatments of four replicate and each replicate comprised eight birds. The pullets were initially fed basal diet for three weeks followed by dietary supplementation with AA at 0 (T1), 300 (T2) and $600 \mathrm{mg} / \mathrm{kg}$ (T3). Feed and water were provided to the pullets ad libitum. Performance and physiological parameters were monitored. Data were subjected to ANOVA and polynomial regression and means separated at $\alpha_{0.05}$. Ambient temperature, relative humidity and temperature humidity index were $29.0 \pm 1.5{ }^{\circ} \mathrm{C}, 71.9 \pm 0.3 \%$ and $26.9 \pm 1.3$, respectively. Feed intake $(\mathrm{kg})(0.89,0.87,0.88)$ and livability $(93.8,96.9,96.9 \%)$ of pullets on T1, T2 and T3, respectively were not significantly affected $(P>0.05)$ by supplemental AA. Weight gain ( $\mathrm{kg})$ of pullets on $T 1(0.36)$ and $T 3(0.42)$ were similar $(P>0.05)$ but were significantly lower $(P<0.05)$ than $T 2(0.47)$. Feed conversion ratio of pullets on T2 (1.89) and T3 (2.09) were significantly lower $(P<0.05)$ than T1 (2.48). Panting rate (Breath/min) of pullets on $T 1$ (231.8) and T2 (225.0) were similar $(P>0.05)$ but significantly higher $(P<0.05)$ than in T3 (207.8). Rectal temperature of pullets on T3 (41.9) was lower than $T 1$ (41.5). In conclusion, dietary supplementation of AA improved performance and physiological response of growing pullets in this study.

Keywords: Point of cage pullets, Rectal temperature, Supplemental ascorbic acid, Temperature humidity index

\section{Introduction}

Heat stress remains a serious impediment to increased poultry production in the tropics. Heat stress in poultry is prompted by combinations of environmental temperature and humidity that prevent the bird's thermoregulatory process from effectively dissipating heat produced during metabolism (Webster, 1983). There is a range of temperature outside which all animals become stressed. Lower temperatures below the requirement of the animal may constitute cold stress while a temperature higher than what the animal can cope with may lead to heat stress.

The thermoneutrality of chickens raised in the tropics used to be between $18-22{ }^{\circ} \mathrm{C}$
(Charles, 2002) and now $18-26{ }^{\circ} \mathrm{C}$ (Holik, 2009). Outside the thermo neutral zone, chickens become uncomfortable and as such a limitation is placed on the attainment of their intrinsic genetic potential thereby resulting to reduction in feed intake, feed efficiency, live weight gain and quality of eggs coupled with increased mortality (Demir et al., 1995; Bollengier et al., 1999). However, the temperature in the hot humid tropical environment of Ibadan, Nigeria, often times exceeds this (Majekodunmi et al., 2013).

There are various strategies to minimize heat stress in poultry birds either by changing their environmental condition or by modification of their diets (Ajakaiye $e t$ 


\section{Performance and physiological response of heat stressed growing pullets}

al., 2010). The viable nutritional strategy during heat period is based on diet balancing in order to cover the needs of stressed birds for amino acids (protein), energy and electrolytes (Balnave, 2004; Daghir, 2009). Nutritional intervention by the use of supplemental vitamins may be the necessary solution to address this menace because their supply in diets does not alter the energy or protein requirement of the animals.

The AA has been implicated in the management of stress related issues in livestock production. Ordinarily, birds will naturally synthesis AA in adequate amount but during stress related activities, the requirement of $\mathrm{AA}$ is greater than the amount synthesized by normal tissues (Balogun et al., 1996) thus the need to be included in diets of chicken. Reports (Abioja et al., 2005; Ogunwole et al., 2012; Majekodunmi et al., 2013) have demonstrated the role of supplemental AA in the alleviation of stress in poultry. Similarly, there has been reported increase in feed intake with AA supplementation (Sahin and Kuck, 2001) while there was reported improvement in the feed conversion ratio by dietary inclusion of AA in poultry diets (Onu, 2009 and Blaha et al., 2010).

Despite avalanche of reports on importance of AA for stress mitigation in poultry production, there has been dearth of information on the appropriate levels of dietary AA supplement to be fed to growing pullets. Also, most reports on stress alleviation in poultry (Sahin and Kuck, 2001; Abioja et al., 2005; Blaha et al., 2010; Majekodunmi et al., 2015) were devoted to broilers (Blaha et al., 2010; Majekodunmi et al., 2013) and laying hens (Genedi, 2000; Cifti et al., 2005; Ajakaiye et al., 2010) with relative dearth of little information on its effect on growing pullets. This study was therefore aimed at investigating the performance and physiological response of growing pullets given diets supplemented with graded levels of AA.

\section{Materials and methods}

Bovan Brown pullets $(\mathrm{n}=96)$ aged 12 weeks weighing $0.81 \pm 0.04 \mathrm{~kg}$ with standard husbandry records were purchased from a reputable farm and allotted to three dietary treatments of four replicates and eight birds per replicate in a completely randomised design. Pullets were initially raised on an isocaloric and isonitrogenous basal diet for the first 3 weeks after which the diets were supplemented with ascorbic acid. Details of the basal experimental diet composition have been documented (Adedeji et al., 2017) and are shown in Table 1. Treatment 1 (T1) is the control with no supplemental AA. Treatment 2 (T2) had $300 \mathrm{mg} / \mathrm{Kg}$ AA while Treatment 3 (T3) had $600 \mathrm{mg} / \mathrm{kg}$ AA. Feed was offered daily and left over weighed weekly to calculate feed intake. Weight gain was measured on a weekly basis while feed conversion ratio was calculated as the ratio of feed intake to weight gain. Mortality was recorded against each replicate; Panting rate (PR) was determined by counting the number of breaths per minute; Rectal temperature (RT) was measured by inserting the probe of a digital thermometer into the rectum of selected pullets; ambient temperature and relative humidity were monitored using digital thermo-hygrotherms mounted within the pen house while Temperature Humidity Index (THI) was calculated according to Zulovich and DeShazer (1990) using the formula:

THI layers $=0.6 \mathrm{Tdb}+0.4 \mathrm{Twb}$.

Where:

THI= Temperature Humidity Index

$\mathrm{Td} b=$ Dry bulb Temperature

Twb $=$ Wet Bulb Temperature 


\section{Adedeji and Ogunwole}

Table 1: Gross composition (\%) of basal diet fed to the growing pullets

\begin{tabular}{|c|c|}
\hline Ingredient & $\%(\mathrm{~kg})$ \\
\hline Maize & 50.80 \\
\hline Soybean meal & 18.00 \\
\hline Wheat offal & 27.85 \\
\hline Oyster shell & 1.00 \\
\hline Bone meal & 1.6 \\
\hline *Vitamin-mineral premix & 0.25 \\
\hline Table salt & 0.30 \\
\hline DL-Methionine & 0.10 \\
\hline L-lysine & 0.10 \\
\hline \multicolumn{2}{|l|}{ Calculated Nutrients } \\
\hline $\mathrm{ME}(\mathrm{Kcal} / \mathrm{kg})$ & 2751.27 \\
\hline Crude Protein (\%) & 16.87 \\
\hline Crude Fibre (\%) & 4.55 \\
\hline Methionine (\%) & 0.37 \\
\hline Lysine (\%) & 0.98 \\
\hline Calcium (\%) & 1.07 \\
\hline Available Phosphorus (\%) & 0.42 \\
\hline \multicolumn{2}{|c|}{$\begin{array}{l}\text { *Vitamin-mineral premix - Vitamin A }-10,000 \mathrm{IU} \text {, Vitamin } \mathrm{D}_{3}-1800 \mathrm{IU} \text {, Vitamin E }-40 \mathrm{mg} \text {, Vitamin } \mathrm{K}- \\
1.43 \mathrm{mg} \text {, Vitamin B } 1-0.7 \mathrm{mg} \text {, Vitamin B2 }-4 \mathrm{mg} \text {, Vitamin B6 }-2.5 \mathrm{mg} \text {, Vitamin B12 }-0.2 \mathrm{mg} \text {, Niacin }- \\
\text { 10mg, Panthothenic }-10,000 \mathrm{mg} \text {, Folic acid }-0.25 \mathrm{mg} \text {, Biotin }-100 \mathrm{mg} \text {, Choline Chloride }-300 \mathrm{mg} \text {, } \\
\text { Manganese-80mg, Zinc }-60 \mathrm{mg} \text {, Iron }-40 \mathrm{mg} \text {, Copper }-80 \mathrm{mg} \text {, Iodine }-0.8 \mathrm{mg} \text {, Selenium }-0.2 \mathrm{mg} \text {, Cobalt - } \\
\text { 0.3mg, Antioxidant-100mg }\end{array}$} \\
\hline
\end{tabular}

\section{Statistical analysis}

Data were subjected to ANOVA and polynomial regression of SAS (2003) and significant means were separated using Duncan's Multiple Range Test of the same software at $\alpha_{0.05}$

\section{Results and discussion}

The ambient temperature and relative humidity of the pen house for the study period is shown in Figure 1. During heat stress, environmental parameters of AT, $\mathrm{RH}$ and Temperature humidity Index (THI) are invaluable tools in the presumptive diagnosis of an animal's state of health, as well as adaptability (Tao and Xin, 2003; Karaman et al., 2007). The AT $\left(29 \pm 1.49^{\circ} \mathrm{C}\right)$ and $\mathrm{RH}(71.93 \pm 0.27 \%)$ were perpetually high during this trial. High temperature and low humidity $\left(32{ }^{\circ} \mathrm{C}\right.$ and $\left.40 \% \mathrm{RH}\right)$ have been reported to be well tolerated by birds while high temperature and high humidity $\left(32{ }^{\circ} \mathrm{C}\right.$ and $\left.90 \% \mathrm{RH}\right)$ are problematic (Lesson and Summers, 2005).

The response of chickens at high temperatures differs with different relative humidity. High temperature when accompanied with high humidity is more detrimental to layer performance than high temperature with low humidity (Ajakaiye $e t$ al., 2010). Thermo-neutral zone (TNZ) is the range of ambient temperature which does not affect regulatory changes in metabolic heat production or evaporative heat loss in birds (Kingma et al., 2012). Dei and Bumbie (2011), reported that diurnal ambient temperature fluctuations usually exceed the TNZ of chickens thus resulting in heat stress. The THI $(26.90 \pm 1.28)$ in this study as shown in Figure 2 were outside the TNZ of chickens thus further suggesting that the chickens were thermally stressed in the rearing period. 
Performance and physiological response of heat stressed growing pullets

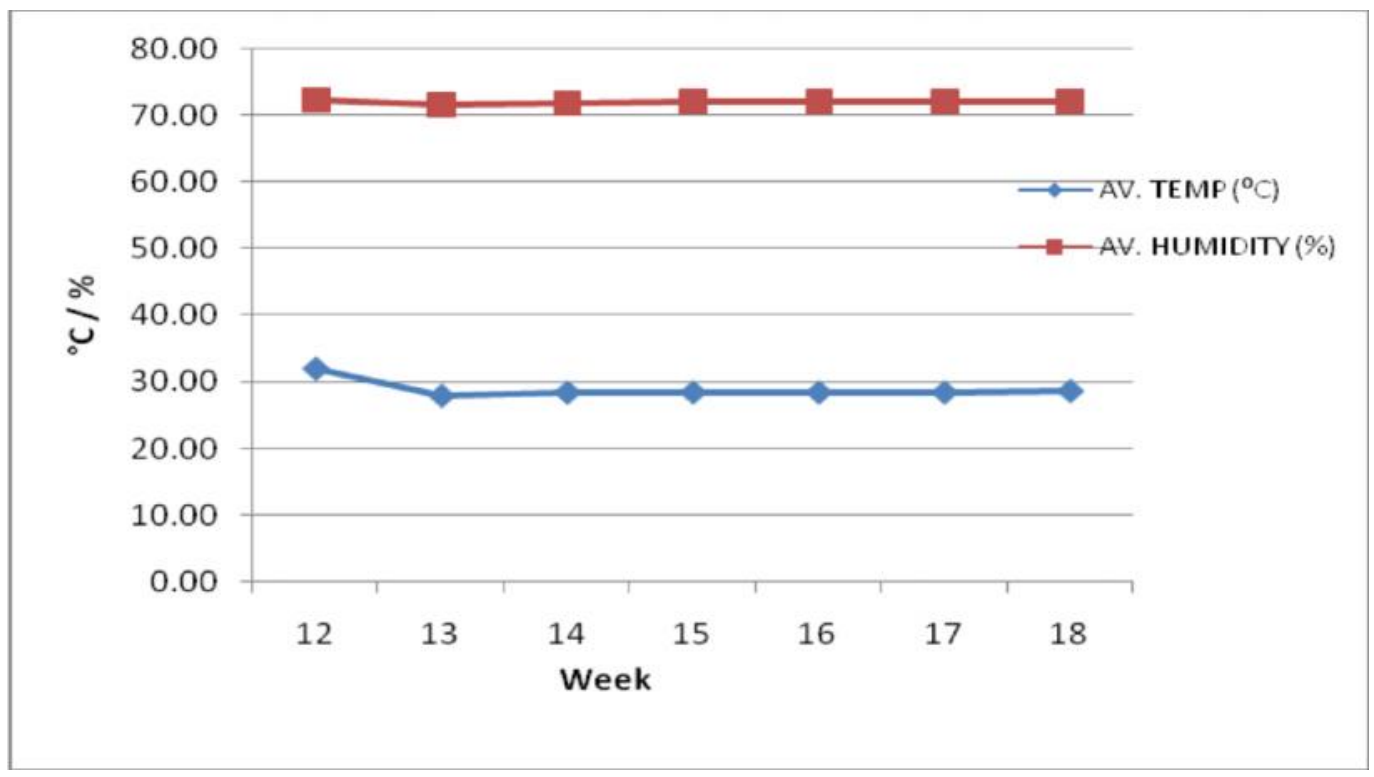

Figure 1: Ambient temperature and relative humidity of the pen house during the trial period

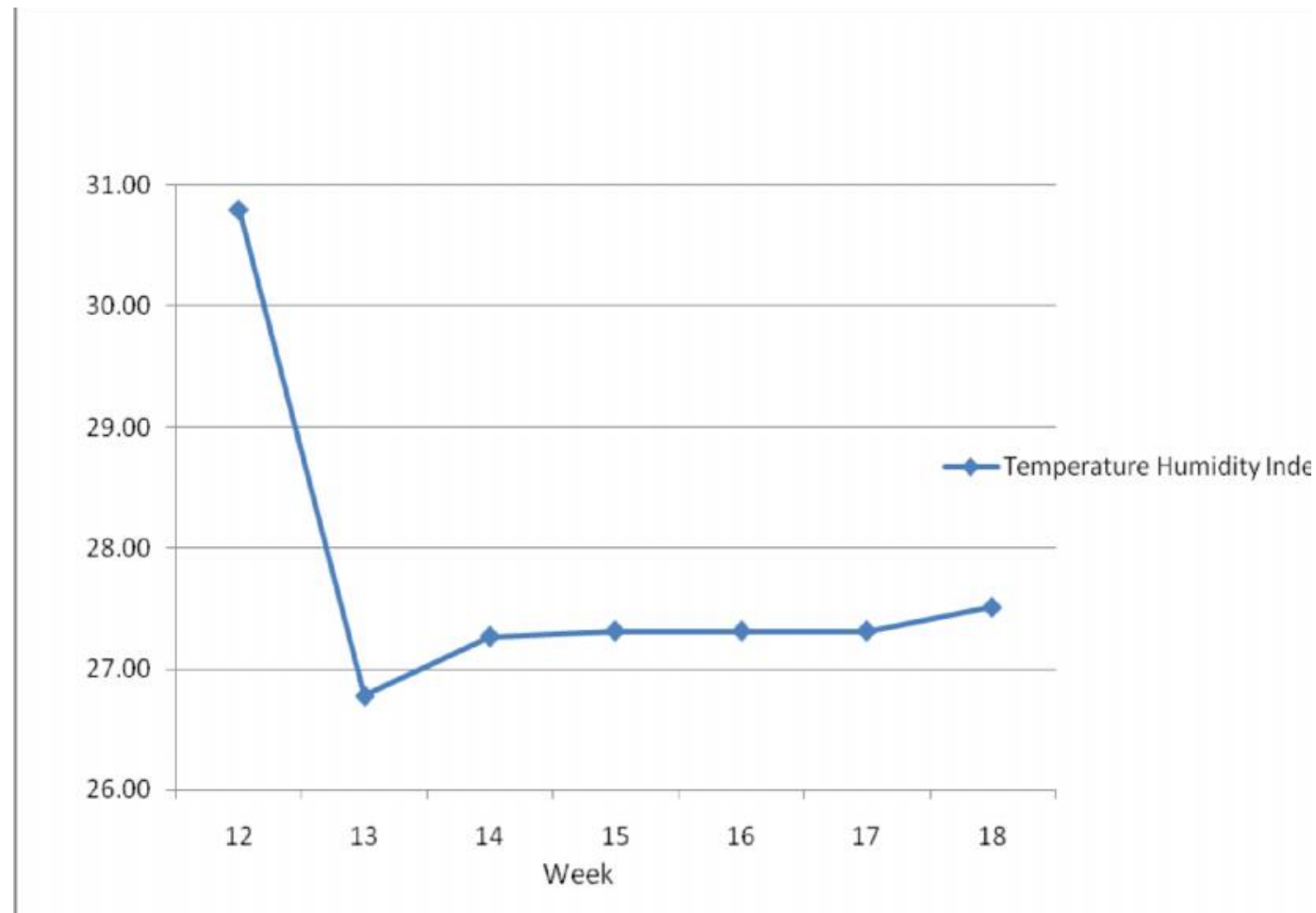

Figure 2: Temp erature humidity index of pen house at the growing phase 


\section{Adedeji and Ogunwole}

Performance of growing pullets fed diets supplemented with AA is shown in Table 2. Final weight, weight changes, feed intake and livability values were within the range of 1.19 (T1) to 1.26 (T2); 0.36 (T1) to 0.41 (T3); 0.87 (T2) to 0.89 (T1) and 93.8 (T1) to
96.9 (T3), respectively. These parameters were however not influenced by dietary inclusion of AA, while weight changes and FCR were significantly different across the treatments with values ranging from 0.36 (T1) to 0.47 (T2) and 1.89 (T2) to 2.48 (T1), respectively.

Table 2: Performance of growing pullets fed diets supplemented with ascorbic acid

\begin{tabular}{lllll}
\hline Parameters & T1 & T2 & T3 & SEM \\
\hline Feed intake $(\mathrm{kg})$ & 0.89 & 0.87 & 0.88 & 0.004 \\
Initial weight $(\mathrm{kg})$ & 0.83 & 0.81 & 0.80 & 0.01 \\
Final weight $(\mathrm{kg})$ & 1.19 & 1.28 & 1.23 & 0.03 \\
Weight gain $(\mathrm{kg})$ & $0.36^{\mathrm{b}}$ & $0.47^{\mathrm{a}}$ & $0.42^{\mathrm{ab}}$ & 0.01 \\
FCR & $2.48^{\mathrm{a}}$ & $1.89^{\mathrm{b}}$ & $2.09^{\mathrm{b}}$ & 0.09 \\
Livability $(\%)$ & 93.8 & 96.9 & 96.9 & 1.78 \\
\hline
\end{tabular}

a, b : means in the same row with different superscripts are significantly different $(\mathrm{p}<0.05)$.

T1: 0mg ascorbic acid; T2: 300mg ascorbic acid; T3: 600mg ascorbic acid; FCR: Feed Conversion Ratio

The variations in the final weight observed in this study were not significantly different $(\mathrm{P}>0.05)$. This observation conformed to the report of Tuleun et al. (2011) and Cifti et al. (2015) in Japanese quail and laying chickens but was however, contrary to the observation of Oso et al. (2013) in turkey and Ogunwole et al. (2015) in broiler chickens fed supplemental AA. Weight changes of pullets on T2 (0.47) and T3 $(0.42)$ were similar $(\mathrm{P}>0.05)$ but were significantly higher $(\mathrm{P}<0.05)$ than 0.36 in birds on $\mathrm{T} 2$. The similarity observed in the weight changes of pullets on $\mathrm{T} 1$ and $\mathrm{T} 3$ could be that the supplementation of AA beyond $300 \mathrm{mg}$ was in excess of dietary need of the pullets thus interfering with weight gain. Contrary to earlier reports (Nwoku and Nwazota, 1989; Demir et al. 1995; Sahin and Kuck, 2001) on increased feed intake with supplemental AA in poultry. Observation from this study conformed to reports (Oniseibo and Alu, 2006; Onu, 2009) that dietary supplementation of vitamin $\mathrm{C}$ had no effect on feed consumption. The relationship between dietary AA supplementation and weight gain in pullets is shown in Figure 1.
Supplemental AA correlated positively with the weight gain of pullets $\left(R^{2}=93.5\right)$. Supplemental AA beyond the maximum level used in this study would further improve weight gained by the pullets. The relationship is represented with the equation:

$\mathrm{Y}=0.000 \mathrm{X}+0.328\left(\mathrm{R}^{2}=93.5\right) \ldots$ Equation 1 The FCR of pullets on T2 (1.89) and T3 (2.09) were similar $(\mathrm{P}>0.05)$ but was significantly lower $(\mathrm{P}<0.05)$ than $\mathrm{T} 1$ (2.48). This observation corroborated earlier documentations (Onu 2009; Blaha et al., 2010) on improved FCR with supplemental AA in poultry diets contrary to other earlier reports (Ogunwole et al., 2013; Lohakhare et al., 2015; Majekodunmi et al., 2015) which did not observe any improvement. The relationship between supplemental AA and FCR in Figure 2 is represented by the equation:

$\mathrm{Y}=-0.001 \mathrm{X}+2.691 \quad\left(\mathrm{R}^{2}=82.9\right)$ Equation 2

This linear relationship also showed that $82.9 \%$ of the observed changes in FCR was due to supplemental AA in the diets of the pullets. 


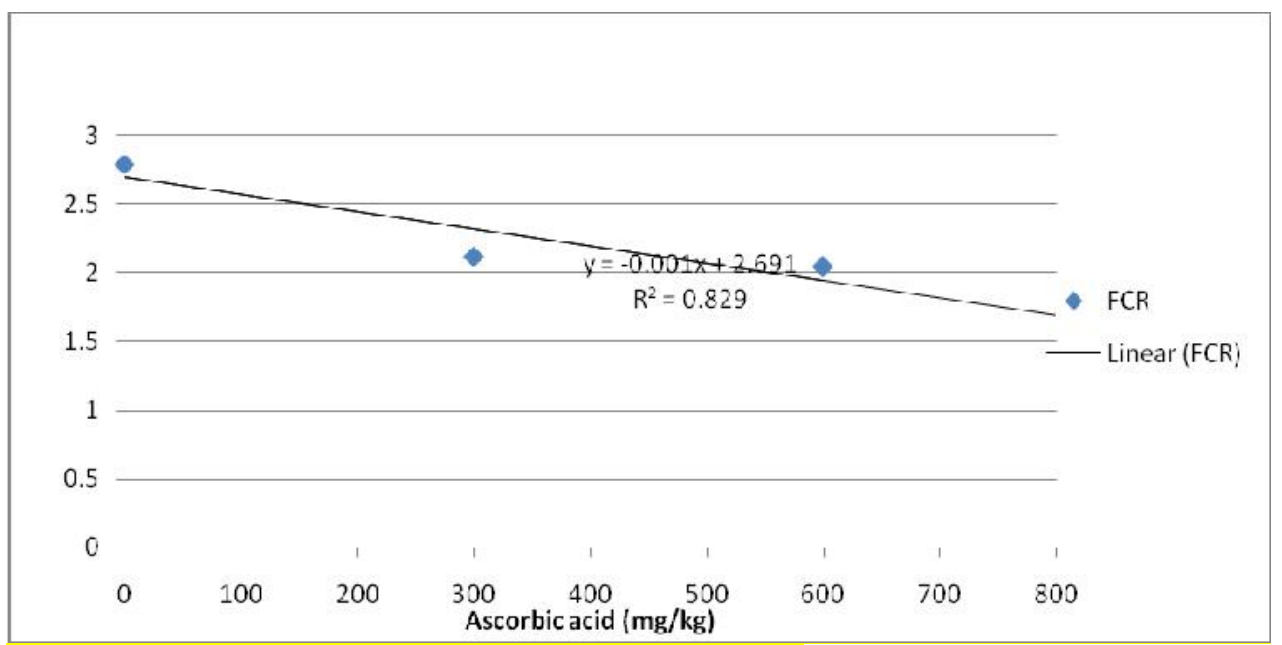

Figure 2: Relationship of supplemental ascorbic acid and FCR

Livability $(\%)$ of pullets on the different treatments was similar $(\mathrm{P}>0.05)$ though there was a numerical improvement with increasing levels of AA inclusion. However, authors (Skyes 1977; Kafri and Cherry, 1984; David and Brake, 1985) reported reduction in the incidences of mortality in chickens on diets with supplemental AA in hot environments. Free radicals generated during stress are harmful to cells in living organisms. Inability of the organism to reduce or hinder the source of free radicals being generated would result in damaged organs, tissues and systems which in turn may lead to eventual death. The relative improvement in livability of birds on supplemental AA in this study could be adduced to the ability of vitamin $C$ to mop excessive free radicals generated during heat stress from causing havoc to the body. 


\section{Adedeji and Ogunwole}

Table 3: Physiological response of growing pullets fed dietary ascorbic acid supplementation

\begin{tabular}{lllll}
\hline & \multicolumn{3}{c}{ Ascorbic acid (mg/kg) } & \\
\cline { 2 - 4 } Parameters & $\mathrm{T} 1$ & $\mathrm{~T} 2$ & $\mathrm{~T} 3$ & SEM \\
\hline Rectal Temperature $\left({ }^{\circ} \mathrm{C}\right)$ & $41.90^{\mathrm{a}}$ & $41.70^{\mathrm{ab}}$ & $41.52^{\mathrm{b}}$ & 0.07 \\
Panting rate (Breath/min) & $231.75^{\mathrm{a}}$ & $225.00^{\mathrm{a}}$ & $207.8^{\mathrm{b}}$ & 3.54 \\
\hline
\end{tabular}

$\overline{\mathrm{a}, \mathrm{b}}$ : means in the same row with different superscripts are significantly different $(\mathrm{p}<0.05)$.

T1: 0mg ascorbic acid; T2: 300mg ascorbic acid; T3: 600mg ascorbic acid

Physiological response of pullets to dietary AA supplementation is shown Table 3 . Birds do not sweat but there is the need for them to release excess heat load to become comfortable. At temperatures beyond $27^{\circ} \mathrm{C}$ chicken become intensely under stress and would resort to means of dissipating heat from the body. Some of the means adopted to naturally cool off the body of excessive heat load includes wing spreading and panting among others. Respiratory rate and cloacal temperature are variables widely used and considered the simplest ones for the evaluation of physiological conditions of animals (Bianca and Kunz, 1978).

Chickens present a significant increased respiratory rate under high temperatures (Silva et al., 2007) with a value up to 165 breaths/min reported in broiler chickens. In this study, panting rate in pullets on $\mathrm{T} 3$ (207.8) was significantly lower than in $\mathrm{T} 2$ (225) and T1 (231), thus emphasising the importance of AA in the alleviation of heat stress in poultry. However, values obtained were higher than 100 to 151 breaths/min observed by Nascimento et al. (2012) in Avian and Cobb strains of broiler chicken exposed to heat.

The body temperature of domestic chickens is maintained within a relatively narrow range that is usually reflected by the upper $41.5^{\circ} \mathrm{C}$ and lower $40.5^{\circ} \mathrm{C}$ limits of a circadian rhythm (Daghir, 1995). This however fluctuates depending on the temperature of environment (Sottnik, 2002). Rectal temperature of pullets on T1 (41.90) in this trial was similar to those on
T2 (41.70) but significantly higher than RT of pullets on T3 (41.52). This showed that supplemental AA up to $600 \mathrm{mg} / \mathrm{Kg}$ (T3) in the pullet diets significantly lowered RT compared with the control. This observation supported the findings of Kutlu and Forbes (1993), though RT in this study were within the body temperature $\left(41-42{ }^{\circ} \mathrm{C}\right)$ documented for normal chickens (Donkoh, 1989). Conversely, Pardue and Thaxton (1986); Genedi, (2000); Majekodunmi et al. (2015) observed no significant effect of supplemental AA on RT of broilers exposed to high temperature.

\section{Conclusion}

Environmental parameters revealed that birds in this study were heat stressed. The AA supplementation improved weight gain, feed conversion and physiological responses of pullets in this study.

\section{Acknowledgement}

Authors are highly appreciative of the cardinal roles of the Tertiary Education Trust Funds in the sponsorship of this research. We also thank and appreciate Folasade Jemiseye, Aderonke Mosuro, and Ireti Oludoyi for assisting in proof-reading and editing of the manuscript.

\section{References}

Abioja, M. O., Osinowo, O. A., Smith, O. F., Eruvbetine D. and Abiona, J. A. 2011. Evaluation of cold water and vitamin $\mathrm{C}$ on broiler growth during hot dry season in SW 
Performance and physiological response of heat stressed growing pullets

Nigeria. Arch. Zootec. 60 (232): 1095-1103.

Adedeji, B. S., Ogunwole, O. A., Jemiseye, F. O., Mosuro, A. O. and Oludoyi, I. O. 2017. Effect of dietary inclusion of vitamin $\mathrm{C}$ on performance and physiological response of growing pullets. Proceedings of the $42^{\text {nd }}$ Annual Conference of the Nigerian Society for Animal Production. Titled: Emerging Challenges Facing Animal Agriculture in Nigeria and the way Forward, held at Landmark University, Omu-Aran, Kwara State, Nigeria. Eds. A. A. Adeloye, E. O. Oyawoye, A. A. Toye and B. T. Adesina, pp. 769773.

Ajakaiye, J. J., Perez-Bello, A., Mollineda-Trujillo, A. 2010. Impact of Vitamins $C$ and $E$ Dietary Supplementation on Leukocyte Profile of Layer Hens Exposed to High Ambient Temperature and Humidity. Acta. Vet. Brno. 79:377-383.

Blaha, J., Draslarova, J. and Kroesna, K. 2000. The effect of vitamin and electrolyte supplement on broiler performance under stress. Agricultural Tropical ET Subtropical.33:

Balnave, D. 2004. Challenges of accurately defining the nutrient requirements of heat-stressed poultry. In: World's Poultry Science Association Invited Lecture. Poult. Sci. 83:5-14.

Balogun, T. F., Afolayan, S. B., Njoku, F. C., Dafwang, I. I. 1996. Effect of Ascorbic Acid and Acetylsalicylic Acid supplementation of broiler diets on performance during the hot season. Samaru J. Agric. Educ.
5:80-86.

Bollengier-lee, S., Williams, P. E. V. and Whitehead, C. C. 1999. Optimal dietary concentration of vitamin $\mathrm{E}$ for alleviating the effect of heat stress on egg production in laying hens. Br Poult. Sci., 1999, 40: 102107.

Charles, D. R. 2002. Responses to the thermal environment. In: Poultry Environment Problems, A guide to solutions (Charles, D.A. and Walker, A.W. Eds.), Nottingham University Press, Nottingham, United Kingdom, pp.1-16.

Ciftci, M., Nihat, E. O. and Guler, T. 2005. Effects of vitamin $E$ and vitamin $\mathrm{C}$ dietary supplementation on egg production and egg quality of laying hens exposed to a chronic heat stress. Revue Med Vet; 156 (2):107-111.

Daghir, N. J. 1995. Poultry Production in Hot Climates. The University Press, Cambridge.

Daghir N. J. 2009. Nutritional strategies to reduce heat stress in broilers and broiler breeders. Loh. Inform. 44:6-15.

David, E. P. and Brake, J. 1985. Relationship of dietary ascorbic acid to broiler breeder performance. Poult. Sci., 64: 20412048.

Dei, H. K. and Bumbie, G. Z. 2011. Effect of net feeding on growth performance of broiler chickens in a hot climate. Br. Poult. Sci. 52:8285.

Demir, E., Öztürkcan, O., Görgülü, M., Kutlu, H. R. and Okan, F. 1995. Sicak kosullarda yumurta tavugu rasyonlarina eklenen vitamin A ve C'nin yumurta özelliklerine etkileri.J.Agric. Fac. Ç.Ü., 10 (4) : 


\section{Adedeji and Ogunwole}

123-132.

Donkoh, A. 1989. Ambient temperature: A factor affecting performance and physiological response of broiler chickens. Int. J. Biometeorol., 33: 259-265.

Genedi, D. M. M. 2000. The role of some anti-stressors on layer performance during hot climate conditions. M.Sc., Thesis Faculty of Agriculture, Cairo University.

Holik, V. 2009. Management of laying hens to minimize heat stress. Lohmann Information 44: 16-29.

Kafri, I. and cherry, J. A. 1984. Supplemental ascorbic acid and heat stress in broiler chicks. Poult.Sci., 63(supp):125.

Karaman, S., Tarhan S. and Ergunes, G. 2007. Analysis of Indoor Climatic Datato Assess the $\quad \mathrm{H}$ e a t Stress of Laying Hens. IJNES; 1(2):65-68.

Kingma, B., Frijns, A. and Lichtenbalt, W. V. 2012. The thermoneutral zone: implication for metabolic studies. Front. Biosci. 4:19751985.

Kutlu H. R. and Forbes, J. M. 1993. Changes in growth and blood parameters in heat-stressed broiler chicks in response to dietary ascorbic acid. Livestock Product Sci., 36, 335-350.

Lohakare, J. D., Ryu, M. H., Hahn, T.W., Lee, J. K.. and Chae, B. J. 2005. Effects of supplemental ascorbic acid on the performance and immunity of commercial broilers. J.Appl. Poult. Res. 14:10-19

Majekodunmi, B. C., Ogunwole, O. A. and Sokunbi, O.A. 2013. Effect of supplemental electrolyte and ascorbic acid on the performance and carcass characteristics of broiler raised during high temperature period in Nigeria. Int. J. of Poult. Sci. 11(2): 125-130

Majekodunmi, B. C., Ogunwole, O. A. and Sokunbi, O. A. 2015. Synergistic Effect of Electrolytes and Ascorbic Acid on Performance and Physiological Response of Broiler Birds in Hot Humid Tropics. International Journal of Agriculture and Forestry, 5(1): 2329

Nascimento, S. T., Oliveira, I. J., da Silva, Mourão, G. B. de Castro, A. C. 2012. Bands of respiratory rate and cloacal temperature for different broiler chicken strains. $R$. Bras. Zootec., 41 (5): 1318-1324.

Njoku P. C. and Nwazota, A. O. U. 1989. Effect of dietary inclusion of ascorbic acid and palm oil on the performance of laying hens in hot tropical environment. Brit. Poultry Sci., 30, 831-840.

Ogunwole, O. A., Majekodunmi, B. C., Olowe, T. O. and Olumide, M. D. 2013. Meat quality and bone characteristics of broiler chickens fed diets supplemented with graded levels of ascorbic acid. Proc. 38th Conf. Nig. Soc. Anim. Prod. Rivers State Univ. of Science and Tech. 17-20 March, pp. 774-776. Eds. B. M. Oruwari, J. P. Alawa, U. I. Oji, O. J. Owen and O. S. George.

Ogunwole, O. A., Oikeh, I. Olowe, T. O., Omotoso, R. R. and Oso, Y.A. A. 2012. Blood profile of broiler starter chickens as affected by diets supplemented with graded levels of ascorbic acid. Proc. 17th Ann. Conf. Animal Science Assoc. of Nigeria. International Conference Centre, Opposite Radio House, Area 8, Abuja, September 9-13 pp. 
203-206. Eds. Akpa, G. N., Dairo, F. A. S., Bawa, G. S., Solomon, I. P., Amaefule, K. U., Odunsi, A. A. and Ladokun, A. O.

Onu, P. N. 2009. Growth performance, carcass characteristics and economic benefits of supplemental ascorbic acid on broiler starters exposed to heat stress. ARPN Journal of Agricultural and Biological Science, 4(5) September 2009. (C2006-2009 Asian Research Publishing $\mathrm{N}$ e t w o r k (A R P N ). www.arpnjournals.com

Oruseibio, S. M. and Alu, E. U. 2006. Responses of broiler birds to supplementation of ascorbic acid (vitamin C.) Nigeria Poultry Science Journal. 4: 12-15

Oso, A. O., Oke, O. E., Abioja, M. O., Abiona, J. A., Agbodo, G. A. and Adebowale, T. O. 2013. "Growth and Physiological Response of Local Turkey (Meleagris gallopavo) Offered Dietary Vitamin C". Pacific Journal of Science and Technology. 14(2):441-447.

Pardue, S. L. and Thaxton. J. P. 1986. Ascorbic acid in poultry: A review. World's Poult. Sci. J. 42:107-123.

Sahin, K. and Kuck, O. 2001. "Effect of Vitamin $\mathrm{C}$ and Vitamin $\mathrm{E}$ on Performance, Digestion of $\mathrm{Nutrient}$ and Carcas s Characteristics of Japanese Quails Reared under Chronic Heat Stress (34c)". J. Anim. Physiol. Anim. Nutr., 85:335-342. 21.

Silva, M. A. N., Barbosa, Filho, J. A. D. and Silva, C. J. M. 2007. Avaliação do estresse térmico em condição simulada de transporte de frangos de corte. Revista
Brasileira de Zootecnia, 36 (4): $1126-1130$.

Sottnik, J. 2002. Climatical factors and their effect on production in animal housing. In: ASAE Annual International Meeting/ CIGR XVth World Congress; Chicago, Illinois, USA: ASAE editors.

Sykes, A. H. 1978. Vitamin C for poultry: some recent research. In: Proceedings of the Roche Symposium London, pp. 5-15.

Tao, X. and Xin, H. 2003. Temperaturehumidity-velocity-index for market size broilers. Nevada, USA: Proceedings of the ASAE Annual International Meeting.

Tuleun, C. D., Adenkola, A. Y. and Afele, T. 2011. Effect of dietary ascorbic acid supplementation on the performance of Japanese (Coturnix coturnix japonica) quails in a tropical environment. Journal of Animal and Plant Sciences, 10 (2): 1268- 1275.

Webster, A. J. F. 1983. Nutrition and the thermal environment in nutritional physiology of farm animals, J.A.F. Rook and P.C. Thomas (Eds.), New York, Longman; pp.: 639-669.

Zulovich, J. M. and DeShazer. J. A. 1990. Estimating egg production declines at high environmental temperatures and humidifies. ASAE Paper No. 90-4021. St. Joseph, Mich.: ASAE.

Received: 13th August, 2017 Accepted: 30th November, 2017 